\title{
RA?EGA
}

O ESPACYO GEOGRÁFICO EM ANÁLISE

\section{COMPATIBILIDADE DA ARBORIZAÇÃO DE RUAS EM CENTROS HISTÓRICOS: ESTUDO DE CASO DE SÃO GABRIEL - RS}

\section{COMPATIBILITY OF TREE PLANTING STREETS IN HISTORIC CENTERS: A CASE STUDY OF SÃO GABRIEL - RS}

\author{
Italo Filippi Teixeira \\ Universidade Federal do Pampa (UNIPAMPA) \\ Professor do curso de Engenharia Florestal \\ São Gabriel, RS \\ e-mail:phylippi@gmail.com
}

\section{Recebido em: 28/04/2015}

Aceito em: 02/09/2015

\section{Resumo}

Os centros históricos constituem um elemento central de uma nova sintaxe do espaço urbano. Enquanto objeto de estudo, são um instrumento privilegiado para analisarmos a dialética urbana da permanência e da mudança e para apreendermos a cidade no seu todo. É um objeto que permite, ao mesmo tempo, dar conta do hiato entre a cidade imaginada e ensaiada pelos projetos e a cidade vivida. Os novos dimensionamentos de usos em concordância com a visão atual dos centros históricos também refletem a sua compatibilização com a inserção de novas estruturas e de um elemento de qualidade de vida que é a arborização. Com o objetivo de analisar a compatibilidade da arborização de ruas com a estrutura edificada e de infraestrutura componente do Centro Histórico do município de São Gabriel - RS foi realizado um censo na vegetação arbóreo-arbustiva presente no referido local. Utilizou-se como instrumento de avaliação um formulário estruturado com quesitos quali-quantitativos. Os resultados demonstraram uma arborização tradicional constituída em sua maioria $(77,15 \%)$ de espécies exóticas, localizadas principalmente em canteiros centrais, de porte mediano, com fuste baixo, plantadas muito próximas do meio-fio em área livre restrita, com compasso inadequado, alto índice de interferência de copa e grande predomínio da incompatibilidade da vegetação.

Palavras-chave: árvore, vegetação urbana, cidade, infraestrutura.

\section{Abstract}

The historic centers are a central element of a new syntax of urban space. As an object of study, are privileged to analyze urban dialectic of permanence and change, and to apprehending the city in its entirety instrument. It is an object that allows at the 


\section{COMPATIBILIDADE DA ARBORIZAÇÃO DE RUAS EM CENTROS HISTÓRICOS: ESTUDO DE CASO DE SÃO GABRIEL - RS}

same time, realizing the gap between the imagined and rehearsed for city projects and city living. The new sizing of uses consistent with the current views of the historic centers also reflect its compatibility with the insertion of new structures and an element of quality of life that is the afforestation. With this the objective of analyzing the compatibility of afforestation of streets with the built structure and the infrastructure component of the Historic Center of São Gabriel - RS census was conducted in vegetation trees and shrubs present in that location. It was used as an evaluation instrument with a structured qualitative and quantitative questions form. The results demonstrated a traditional afforestation consists mostly $(77.15 \%)$ of exotic species, mainly located in medians, median size, low stem, planted too close to the curb in restricted free area with inappropriate compass high level of interference from the crown and the predominance of incompatible vegetation.

Keywords: tree, urban vegetation, city, infrastructure.

\section{INTRODUÇÃO}

As cidades, desde as pequenas aglomerações urbanas da antiguidade às atuais metrópoles globais, sempre polarizaram importantes funções sociais, económicas, patrimoniais e cívicas, constituindo-se um legado das sociedades passadas e, uma plataforma para as vindouras, sendo um espaço de transição por excelência. Esse conjunto de atividades económicas e sociais, funções cívicas, habitacionais e patrimoniais, que se constituem o motor da vida urbana, desempenhadas pelas cidades tinham o seu eixo gravitacional nos seus centros históricos, a sua origem e área mais central.

Segundo Salgueiro (2005, p.259), os centros históricos para além de serem as partes mais antigas da cidade, constitui-se como uma sucessão de testemunhos de várias épocas, monumento que nos traz vivo o passado, nos dá a dimensão temporal com a sequência dos fatos que estruturam as identidades.

Os centros históricos das cidades constituem-se ainda hoje como espaços urbanos muito identificáveis, de alta qualidade representativa, cheios de elementos emblemáticos e a cidade como tal, com todos os seus atributos, reconhece-se no centro: o nome, a identidade, a representação, os monumentos, a integração coletiva, a qualidade urbana encontram aí o seu eixo gravitacional, sendo por tal fundamental a sua salvaguarda e valorização (BOHIGAS, 1998, p.203).

$\mathrm{Na}$ segunda metade do século $X X$, o desenvolvimento das forças de descentralização, alterou profundamente a composição e funções das áreas históricas das cidades, emergindo preocupações relacionadas com o destino destas 
e, com a sua eventual morte anunciada. Com efeito, a partir de cerca dos anos 50, a explosão do fenómeno de suburbanização, desfaz a anterior e linear matriz de cidade, as metrópoles e as cidades alongaram-se, novas morfologias urbanas apareceram, novas centralidades periféricas apareceram, a cidade perdeu a sua centralidade radial e o urbano espraiou-se (MARQUES, 2005, p.41).

Este modelo acabou por colocar graves problemas às áreas urbanas, pela insustentabilidadede um maior consumo de solo e pelo aumento das deslocações pendulares, o que por um lado resultou num aumento do consumo de energia, e por outro levou ao abandono dos centros históricos das cidades, deixando-os degradados e envelhecidos (CAVÉM, 2007, p.16).

Apesar de todas estas modificações, o declínio das áreas históricas das cidades só se sente com maior intensidade a partir dos anos 70 , quando o progresso na tecnologia dos transportes e comunicações, acarreta importantes alterações na organização económica e social e, portanto, também nos modos de produção e de apropriação do território, na estrutura das cidades (SALGUEIRO, 1999, p.226). Estas transformações decorrentes do pós-guerra e, características da cidade pósindustrial, levaram ao declínio do centro histórico tradicional das cidades e à emergência de novas centralidades, frequentemente albergadas pelas coroas periféricas das cidades.

De fato, uma das mais óbvias manifestações dos problemas dos centros históricos, é a sua obsolescência física, que decorre em paralelo com a obsolescência funcional dos edifícios, infra-estruturas inadequadas e as mudanças nos requisitos de acessibilidade dos utilizadores das áreas urbanas (ROBERTe SYKES, 2004, p.25).

A estrutura edificada dos centros históricos para além de ser o suporte físico das funções habitacional, de comércio e serviços lá existentes, ou seja, a base, o pano de fundo onde estas assentam, é igualmente importante na definição bidimensional e tridimensional dos espaços públicos envolventes, pois dela depende a configuração volumétrica dos mesmos (ALVES, 2003, p. 33).

$\mathrm{O}$ crescimento dos espaços urbanos e das atividades que aí se desenvolvem promove um conjunto vasto de alterações a diferentes níveis tais como: definição de um microclima específico, redução da biodiversidade, redução de zonas permeáveis 
e de espaços relacionados com a natureza, aumento de poluição, resíduos e consumo dos recursos naturais e que vão naturalmente levar a alterações no comportamento do material arbóreo (COSTA, 2007). Essa vegetação que convive com a estrutura urbana, conforme Mascaró e Mascaró (2010, p.13) caracterizam os espaços da cidade por suas formas, cores e modo de agrupamento; são elementos de composição e de desenho urbano ao contribuírem para organizar, definir e até delimitar esses espaços.

Conforme Bonametti (2003, p.52) a importância da vegetação vem variando ao logo do tempo com os diversos povos e suas gerações. Enquanto, para alguns, a presença das plantas era de máxima relevância para a sobrevivência da comunidade, para outros, elas tinham um caráter meramente estético. Nos dias atuais, a presença da vegetação dentro dos centros urbanos vem adquirindo extrema importância, pois quebra a artificialidade do meio, além de possuir um papel primordial na melhoria da qualidade do mesmo. Dessa forma, a arborização urbana vem se tornando cada vez mais um agente importante na melhoria do microclima local, assim como na diminuição da poluição, sem contar o papel estético inerente ao seu próprio uso.

As árvores, por suas características naturais, proporcionam muitas vantagens ao homem que vive na cidade, sob vários aspectos: proporcionam bem estar psicológico ao homem; proporcionam melhor efeito estético; proporcionam sombra para os pedestres e veículos; protegem e direcionam o vento; amortecem o som, amenizando a poluição sonora; reduzem o impacto da água de chuva e seu escoamento superficial; auxiliam na diminuição da temperatura, pois, absorvem os raios solares e refrescam o ambiente pela grande quantidade de água transpirada pelas folhas; melhoram a qualidade do ar; preservam a fauna silvestre, conforme Pivetta e Silva Filho (2002, p 2).

Cada cidade teve seu processo particular de crescimento e urbanização, tendo suas características peculiares e exigências, devendo a arborização ser feita através do planejamento ou replanejamento, considerando as espécies da região, características naturais do clima e condições topográficas e estruturais da cidade. A disputa entre as árvores nas calçadas e as redes elétricas pelo mesmo espaço é, sem dúvida, um dos principais problemas existentes na arborização viária de uma 
cidade, principalmente porque a tendência de plantar arbustos ou espécies de pequeno porte para que estes não interfiram na rede, assim como a poda dos galhos que já estão comprometidos com ela, ainda são as opções mais usadas pelos órgãos responsáveis (VELASCO et al., 2006, p.680).

$A$ vegetação no ambiente urbano está sujeita às condições adversas domeio, que provocam o estresse e prejudicam o seu desenvolvimento. Vários fatores podem ser considerados como críticos, tais como: poluição do solo e ar, compactação do solo, espaço limitado para raízes e parte aérea, danos mecânicos, insetos e doenças (FOSTAD e PEDERSEN, 1997, p. 155).

As árvores das ruas levam uma vida marginal, suas raízes presas entre as fundações das edificações e das ruas, enroscadas entre as linhas de telefones, eletricidade, gás e água, e envoltas por um solo compacto e infértil. Seus troncos são entalhados pelos pára-choques dos automóveis, correntes de bicicletas e até pelas grades instaladas para protegê-las. Seus galhos são podados pelos ônibus. Folhas e cascas são tostadas no calor refletido pelo calçamento e pelos muros ou condenadas a uma sombra perpétua pelos edifícios adjacentes. As raízes são encharcadas ou ressecadas pelo excesso ou pela falta de água; em qualquer caso, sua capacidade de fornecer nutrientes essenciais à árvore é drasticamente reduzida. $O$ fato de a árvore de ruas e calçadas sobreviver de alguma forma é mais surpreendente do que o de ser tão curta sua média de vida (SPIRN, 1995, p.193 e 194).

Em relação à arborização urbana, tudo se considera, como a largura das calçadas e das ruas, sua orientação, a proximidade e o porte das edificações, a topografia do terreno, a natureza do solo, o clima, num contexto tridimensional. Bem como também as exigências funcionais do zoneamento urbano (PAIVA e GONÇALVES, 2004, p. 132).

Isto posto o objetivo deste trabalho foi analisar a compatibilidade da arborização de ruas com a estrutura edificada e de infraestrutura componente do Centro Histórico do município de São Gabriel - RS. 


\section{MATERIAL E MÉTODOS}

O presente estudo foi realizado no município de São Gabriel (figura 1), localizado na fronteira oeste do Estado do Rio Grande do Sul, as margens da BR290 e é banhado pelas águas do rio Vacacai, fazendo divisa com os municípios de Rosário do Sul, Lavras do Sul, Dom Pedrito, Cacequi, Dilermando de Aguiar, Vila Nova do Sul, São Sepé e Santa Maria. Tem uma população de 60.425 habitantes e a sua área corresponde a $5.024 \mathrm{~km}^{2}$, o clima do município é o subtropical onde a temperatura media é de $26^{\circ} \mathrm{C}$, a altitude é de $114 \mathrm{~m}$ acima ao nível do mar (IBGE, 2014).

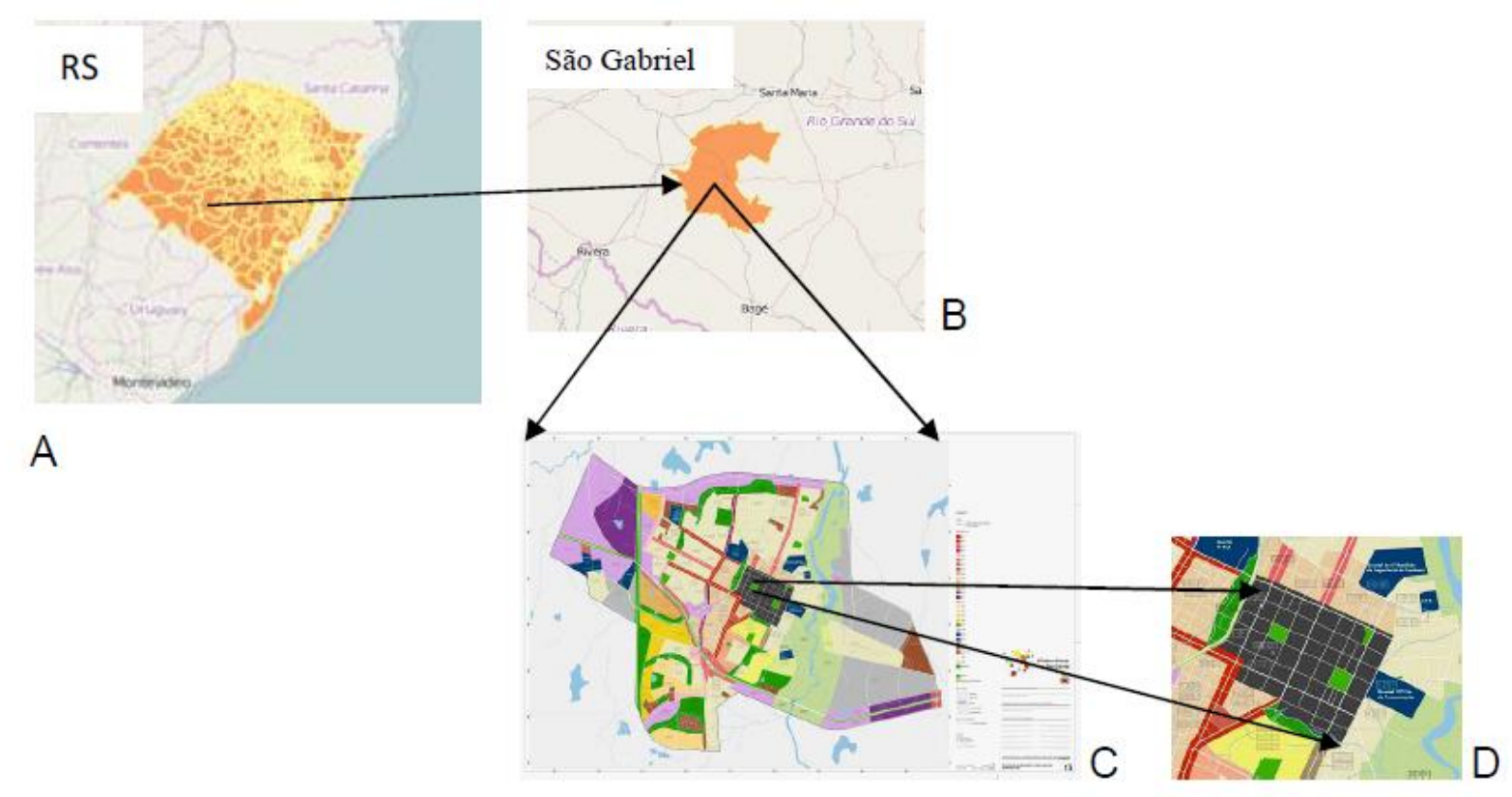

Figura 1: A - Localização do município de São Gabriel, RS, do global ao local; B - Localização da sede do município e (C) do Centro Histórico.

Fonte: IBGE (2014) e Prefeitura Municipal de São Gabriel (2014), respectivamente.

Neste município, no segundo semestre de 2014, desenvolveu-se um censo da arborização de ruas da área central denominada como Centro Histórico conforme lei complementar no 002/08, de 02 de junho de 2008 (PREFEITURA MUNICIPAL DE SÃO GABRIEL, 2014), que institui o Plano Diretor de Desenvolvimento Urbano e Ambiental de São Gabriel e dispõe sobre o desenvolvimento urbano.

O mesmo apresenta 0 maior conjunto arquitetônico de residências consideradas como patrimônio histórico do município, constituído de 27 vias distribuídas entre avenidas, ruas e travessas. Nestas, mediante um formulário estruturado, foram obtidas as seguintes informações: 
a) Endereço - lado esquerdo ou direito e no;

b) Localização - exemplar plantado na calçada ou canteiro central.

c) Espécie - identificação da espécie vegetal pelo nome comum. Os exemplares que não tiveram identificação foram levados ao Herbário Bruno Irgang da Universidade Federal do Pampa Campus São Gabriel para análise, identificação e tombados no patrimônio do mesmo, quando fosse o caso;

d) Origem - nativa $(N)$ ou exótica $(E)$;

e) Altura total $(\mathrm{H})$ - altura total da espécie vegetal, em m;

f) Altura do fuste (hf) - altura da espécie vegetal entre o colo da mesma e a primeira inserção de galho vivo, em m;

g) Caracterização do ambiente:

- distância do meio-fio (DMF) - distância da parte interna do meio fio até o colo da planta, em m;

- distância da esquina(DE) - distância da esquina até a primeira árvore, em m;

- distância da construção (DC) - distância do tronco da árvore até a parede deprédios e/ou casas construídas sem recuo, em m;

- distância do muro (DM) - distância do tronco da árvore até o lado externo do muro, em $\mathrm{m}$;

- largura da calçada (LC) - distância entre o lado externo do muro até o meio fio, em $\mathrm{m}$;

- área livre de pavimentação: superfície livre de pavimentação na calçada destinada ao plantio de espécie arbóreo-arbustiva e que permite a passagem de água da chuva, aeração do solo e adubações futuras: ampla $(A)$ - área livre igual ou superior a $1 \mathrm{~m}^{2}$; regular $(R G)$ - igual a $0,5 \mathrm{~m}^{2}$; restrita $(R S)$ - área livre inferior a $0,5 \mathrm{~m}^{2}$; inexistente (I) - quando a área pavimentada encobre todo o colo da planta - compasso (C) - distância entre duas espécies vegetais, em m;

h) Interferência da copa (IC) - expressa a interferência da tridimensionalidade da copa em relação a pedestres e/ou veículos: sem interferência no trânsito de pedestres e/ou veículos (1); com interferência no trânsito de pedestres e/ou veículos (2);

i) Compatibilização: 
- compatível (C) - quando o espaço que o comporta permite o seu desenvolvimento sem necessidade de intervenção mecânica;

- medianamente compatível (MC) - requer poda leve, porém sistemática para controle do tamanho e da forma da copa;

- pouco compatível (PC) - requer poda pesada e sistemática para controle do tamanho e da forma da copa;

- incompatível (I) - quando o desenvolvimento do vegetal está comprometido em função de estruturas, como muros, fiação elétrica, postes diversos, construções e outras formas de vegetação, e sua permanência poderá incorrer em um desenvolvimento inadequado ou até mesmo em riscos para essas estruturas e para a população em geral.

Os dados gerados foram tabulados na planilha EXCEL para obtenção de médias e frequências absolutas e relativas.

\section{RESULTADOS}

A tabela 1 demonstra a composição florística da arborização de ruas do Centro Histórico de São Gabriel-RS. A composição florística é muito semelhante à de outras cidades brasileiras que apresentam um grande predomínio de espécies exóticas em detrimento das nativas. No censo realizado observou-se que $77,15 \%$ da arborização é constituída de espécies exóticas e dentre estas, duas constituem mais de $50 \%$ da arborização (Extremosa e Ligustro) e dentre as 10 mais frequentes ocorrem 6 exóticas com 67,1\% do total (tabela 1).

Situação semelhante foi observado por Silva et al (2007, p. 49) em inventário realizado na arborização dobairro centro de Pato Branco-PR, onde aespécie mais abundante foi o Ligustrum lucidum (Ligustro), com 62,4\%. A segunda espécie que apareceu com maior freqüência foi a Lagerstroemia indica (Extremosa), a qual também é exótica e por apresentar porte reduzido é frequentemente usada para a arborização das cidades.

Salviet al. (2011, p.237) ao avaliar as nove vias da cidade de Porto Alegre-RS que apresentam uma distribuição de árvores de ambos os lados formando o chamado "túnel verde" também observaram a alta representatividade das espécies exóticas, pois do total de registros efetuados o Jacaranda mimosifolia representou 


\section{COMPATIBILIDADE DA ARBORIZAÇÃO DE RUAS EM CENTROS HISTÓRICOS: ESTUDO DE CASO DE SÃO GABRIEL - RS}

48\%do total, Tipuana tipu 10,9\%, Lagerstroemia indica 10,7\%, Ligustrum lucidum $5,8 \%$ e outras 57 espécies distribuídas nos $24,6 \%$ restantes.

Este cenário corrobora o termo "homogeneização biótica" proposto por Alvey (2007, p.197) para o fenômeno de substituição das espécies nativas por exóticas em ecossistemas urbanos. Esse fenômeno é associado à escolha das espécies e também às alterações das condições ambientais locais que, por sua vez, passam a não ser mais apropriadas às espécies nativas.

Silva Filho e Bortoleto (2005, p.974) ao analisar a arborização da Estância de Águas de São Pedro - SP constaram também que a diversidade de espécies encontrada na arborização viária em condições brasileiras tem sido relativamente baixa, prevalecendo a sua homogeneidade.

Tabela 1 - Valores de frequência absoluta (FA) e relativa (FR), localização e origem das espécies identificadas no censo do Centro Histórico de São Gabriel - RS.

\begin{tabular}{|c|c|c|c|c|c|c|c|}
\hline \multirow[t]{2}{*}{ Nome comum } & \multirow[t]{2}{*}{ Nome botânico } & \multicolumn{2}{|c|}{ Localização } & \multicolumn{2}{|c|}{ Origem } & \multirow[t]{2}{*}{ FA } & \multirow[t]{2}{*}{ FR } \\
\hline & & C & $\mathrm{CC}$ & $\mathrm{N}$ & $E$ & & \\
\hline Extremosa & Lagerstroemia indica $\mathrm{L}$ & 95 & 77 & & $\mathrm{X}$ & 172 & 30,3 \\
\hline Ligustro & Ligustrum japonicum Thunb.. & 25 & 93 & & $\mathrm{X}$ & 118 & 20,8 \\
\hline Tipuana & Tipuana tipu (Benth.) Kuntze & 34 & 15 & & $\mathrm{X}$ & 49 & 8,6 \\
\hline Butia & Butia eriospatha (Mart. exDrude) Becc. & 5 & 19 & $\mathrm{X}$ & & 24 & 3,9 \\
\hline Ipê-roxo & Handroanthus heptaphyllus (Vell.) Mattos & 14 & 8 & $\mathrm{X}$ & & 22 & 3,9 \\
\hline Árvore-da-china & Koelreuteria bipinnata Franch. & 17 & & & $\mathrm{X}$ & 17 & 3,0 \\
\hline luca & Yucca elephantipes Regel & 14 & & & $\mathrm{X}$ & 14 & 2,5 \\
\hline Paineira & Ceiba speciosa (A. St.-Hil.) Ravenna & & 13 & $\mathrm{X}$ & & 13 & 2,3 \\
\hline Ipê-amarelo & Handroanthus chrysotrichus (Mart. ex DC) Mattos & & 13 & $\mathrm{X}$ & & 13 & 2,3 \\
\hline Figueira & Ficus benjamina L. & 3 & 8 & & $\mathrm{X}$ & 11 & 1,9 \\
\hline Platano & Platanus $X$ acerifolia (Aiton) Wild & 10 & & & $\mathrm{X}$ & 10 & 1,8 \\
\hline Jerivá & Syagrus romanzoffiana (Cham.) Glassman & 6 & 3 & $\mathrm{X}$ & & 9 & 1,6 \\
\hline Jambolão & Syzygium cumini Lamarck & & 8 & $\mathrm{X}$ & & 8 & 1,4 \\
\hline Jacarandá-mimoso & Jacaranda mimosifolia D. Don. & 1 & 6 & & $\mathrm{X}$ & 7 & 1,2 \\
\hline Limoeiro & Citrus aurantifolia (Christm.) Swingle & & 7 & & $\mathrm{X}$ & 7 & 1,2 \\
\hline Amoreira & Morus nigra L. & & 5 & & $\mathrm{X}$ & 5 & 0,88 \\
\hline Pitangueira & Eugenia uniflora L. & & 5 & $X$ & & 4 & 0,70 \\
\hline
\end{tabular}




\section{COMPATIBILIDADE DA ARBORIZAÇÃO DE RUAS EM CENTROS HISTÓRICOS: ESTUDO DE CASO DE SÃO GABRIEL - RS}

\begin{tabular}{|c|c|c|c|c|c|c|c|}
\hline Sibipiruna & Caesalpinea peltophoroides Benth. & & 4 & $\mathrm{X}$ & & 4 & 0,70 \\
\hline Goiabeira & Psidium guajava $\mathrm{L}$. & 1 & 3 & $\mathrm{X}$ & & 4 & 0,70 \\
\hline Uva-do-japão & Hovenia dulcis Thumb. & & 4 & & ; & (Co & nua) \\
\hline Alamo-prateado & Populus alba L. & 4 & & & $x$ & 4 & 0,70 \\
\hline Palmeira-real & Washingtonia filifera (Lindl.) $\underline{\text { H.Wendl. }}$ & 1 & 3 & & $\mathrm{X}$ & 4 & 0,70 \\
\hline Canafístula & Peltophorum dubium (Sprengel) Taubert) & & 3 & $\mathrm{X}$ & & 3 & 0,53 \\
\hline Caquizeiro & Diospyrus kaki L. & 3 & & & $\mathrm{X}$ & 3 & 0,53 \\
\hline Cinamomo & Melia azedarach $\mathrm{L}$. & & 1 & & $\mathrm{X}$ & 3 & 0,53 \\
\hline Chapéu-de-napoleão & Thevetia peruviana (Pers). K. Schum. & & 3 & & $\mathrm{X}$ & 3 & 0,53 \\
\hline Araucaria & Araucaria angustifólia (Bertol.) Kuntze & 3 & & $\mathrm{X}$ & & 3 & 0,53 \\
\hline Abacateiro & Persea americana Mill. & & 2 & & $\mathrm{X}$ & 2 & 0,35 \\
\hline Carobinha-louca & Tecoma stans (L.) Juss ex. Kenth & 2 & & & $\mathrm{X}$ & 2 & 0,35 \\
\hline Cheflera & Schefflera actinophylla (Endl.) .A.T.Harms & & 2 & & $\mathrm{X}$ & 2 & 0,35 \\
\hline Escova-de-garrafa & Callistemon speciosus (Bonpl.) & & 2 & & $\mathrm{X}$ & 2 & 0,35 \\
\hline Angico-vermelho & Parapiptadenia rígida (Benth.) Brenan & & 2 & $\mathrm{X}$ & & 2 & 0,35 \\
\hline Ingá & Inga marginata Wild & & 2 & $\mathrm{X}$ & & 2 & 0,35 \\
\hline Ipê-ouro & Handroanthus albus (Cham.) Mattos & 2 & & $\mathrm{X}$ & & 2 & 0,35 \\
\hline Tuia & Thuja occidentalis L. & & 2 & & $\mathrm{X}$ & 2 & 0,35 \\
\hline Figueira & Ficus clusiifolia Schott & 1 & 1 & $\mathrm{X}$ & & 2 & 0,35 \\
\hline Ficus & Ficus benjamina $\mathrm{L}$. & 1 & 1 & & $\mathrm{X}$ & 2 & 0,35 \\
\hline Aroeira-preta & Lithraea molleoides (Vell.) Engl. & & 1 & $\mathrm{X}$ & & 1 & 0,18 \\
\hline Falsa-seringueira & Ficus elástica Roxb. & & 1 & & $\mathrm{X}$ & 1 & 0,18 \\
\hline Mangueira & Mangifera indica L. & & 1 & & $\mathrm{X}$ & 1 & 0,18 \\
\hline Nespereira & Eriobotrya japonica (Thunb.) Lindl. & & 1 & & $\mathrm{X}$ & 1 & 0,18 \\
\hline Canela & Ocotea longifolia Kunth. & 1 & & $\mathrm{X}$ & & 1 & 0,18 \\
\hline Brunfelsia & Brunfelsia uniflora (Pohl.) D. Don & & 1 & $\mathrm{X}$ & & 1 & 0,18 \\
\hline Pingo-de-ouro & Duranta repens $\mathrm{L}$. & 1 & & & $\mathrm{X}$ & 1 & 0,18 \\
\hline Amendoim-bravo & Pterogines nitens Tul & 1 & & $\mathrm{X}$ & & 1 & 0,18 \\
\hline Espirradeira & Nerium oleander L. & & 1 & & $\mathrm{X}$ & 1 & 0,18 \\
\hline \multirow[t]{2}{*}{ Piracanta } & Pyracantha coccínea Roem. & & 1 & & $\mathrm{X}$ & 1 & 0,18 \\
\hline & & & & & & 568 & 100 \\
\hline
\end{tabular}

(Continuação) 
O maior desafio da arborização urbana atualmente é a busca pela valorização da flora local. Contudo, é sabido que maiores esforços principalmente no desenvolvimento de pesquisas sobre o comportamento e a adaptação de espécies nativas no ambiente urbano são necessárias e devem ser incentivadas pelo poder público das cidades, já que são os principais interessados nessas informações, pois o planejamento equivocado e o uso incorreto das espécies certamente ocasionarão prejuízos aos cofres públicos (EMER et al., 2011, p. 6).

Neste contexto a altura do fuste é um dado bastante revelador sobre as atuais condições de conflito da vegetação presente na arborização estabelecendo um potencial manejo a ser executado principalmente relacionado a poda de condução das mudas ou das árvores. No caso em estudo além da arborização caracterizar-se fisicamente como de indivíduos senis ocorrem problemas de manejo efetivamente, pois a vegetação implantada apresenta $81,80 \%$ dos exemplares com fuste de $0,1 \mathrm{~m}$ até $2 \mathrm{~m}$, ou seja, o conflito com pedestres, mas principalmente com veículos é muito grande principalmente nas vias com canteiros centrais estreitos (gráfico1).

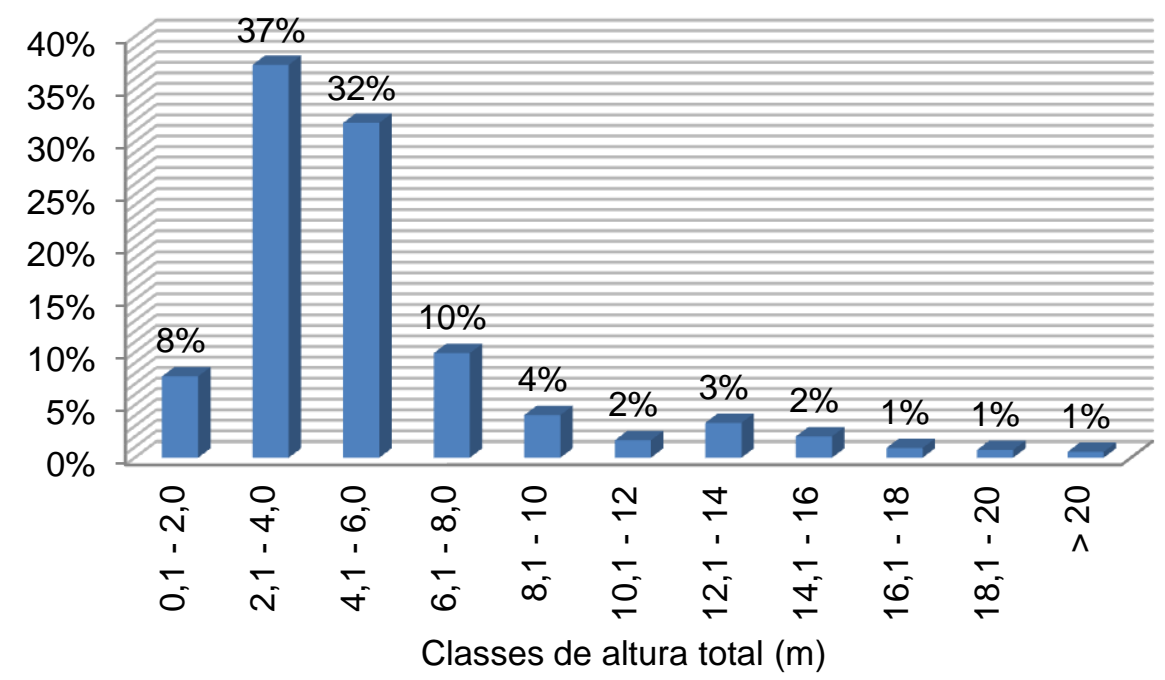

Gráfico 1 - Distribuição das classes de altura do fuste dos exemplares arbóreos ocorrentes na arborização viária do Centro Histórico de São Gabriel - RS.

Sampaio (2006, p.83) ao analisar a arborização de vias públicas das principais zonas do Plano Piloto de Maringá-PR verificou que das 26101 árvores 


\section{COMPATIBILIDADE DA ARBORIZAÇÃO DE RUAS EM CENTROS HISTÓRICOS: ESTUDO DE CASO DE SÃO GABRIEL - RS}

existentes no local, a altura média da bifurcação obtida dos dados analisados foi de 2,07 metros.

Corroborando os resultados relacionados ao fuste, observa-se através do gráfico 2, que a maioria (45\%) dos exemplares componentes da arborização de ruas do Centro Histórico está nas classes de 0,1 - $4 \mathrm{~m}$, ou seja, vegetação com porte baixo considerando-se que estão localizados em calçadas conflitando-se diretamente com os pedestres e também nos canteiros centrais com pedestres e veículos de um modo em geral. Um ponto a considerar é o baixo potencial de conflito com a rede de energia elétrica.

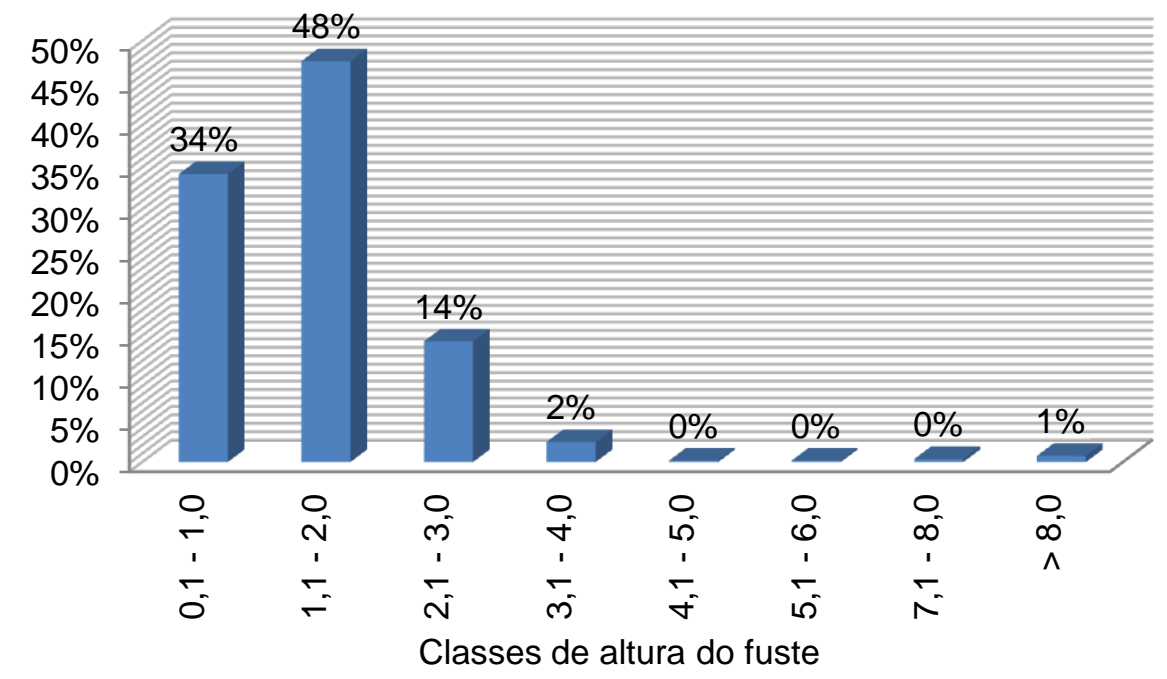

Gráfico 2 - Distribuição das classes de altura total dos exemplares arbóreos ocorrentes na arborização viária do Centro Histórico de São Gabriel - RS.

A análise da distancia do meio fio até a árvore (gráfico 3) demonstrou o que posteriormente também será observado no estudo da área livre, ou seja, uma falta de orientação técnica no momento do plantio deixando a muda muito próxima do meio fio até mesmo derivado da área livre restrita e por não conhecer o potencial desenvolvimento da espécie. Com isto os resultados observados através da figura 3 demonstram que a maioria, $62,26 \%$, está na classe até $0,5 \mathrm{~m}$ do meio-fio. Este fato é recorrente em muitas cidades brasileiras, ou seja, a implantação da arborização ocorrendo por parte dos munícipes sem nenhum acompanhamento técnico. $\mathrm{Na}$ verdade estas ações ocorrem pela omissão do Poder Público. 


\section{COMPATIBILIDADE DA ARBORIZAÇÃO DE RUAS EM CENTROS HISTÓRICOS: ESTUDO DE CASO DE SÃO GABRIEL - RS}

Ruschel e Leite (2002, p.15) ao analisar a área central de Lageado-RS observaram que a distância entre as espécies vegetais componentes da arborização e a face interna do meio-fio indicou que $68,1 \%$ do total encontraram-se no intervalo entre 10 a $50 \mathrm{~cm}$. Cabe ressaltar que 13,6\% estão encostados no meio-fio, fato que pode significar problemas futuros de deslocamento do mesmo, já que muitas árvores observadas nessa situação acabaram causando esse transtorno.

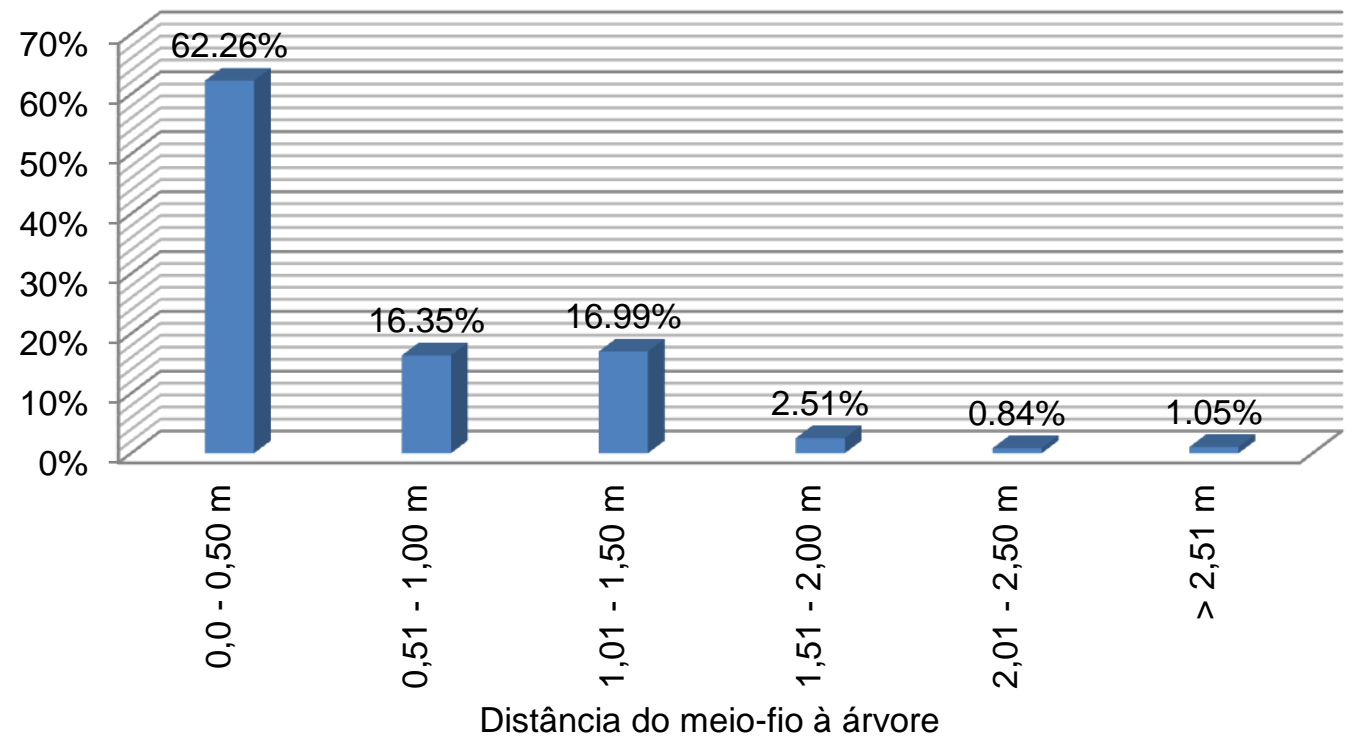

Gráfico 3 - Distribuição das classes de distância do meio-fio aos exemplares arbóreos ocorrentes na arborização viária do Centro Histórico de São Gabriel - RS.

Contrariando esta situação foi encontrado em cidades planejadas e com maior tradição na arborização uma realidade diferente. A área do plano piloto de Maringá-PR apresentou um valor médio do eixo da árvore até o meio fio de 1,35 metros, superior aos 1,2 metros encontrados na média de toda arborização viária de Maringá em 1988 (MILANO, 1988, p.76). Entretanto Maringá possui 89,17\% das árvores plantadas na área do plano piloto a uma distância igual ou superior a 1 metro do meio fio, ou seja, dentro do recomendado. Curitiba possui aproximadamente $60 \%$ dentro do padrão recomendado (MILANO, 1988, p.76) e Recife apenas 15\% (BIONDI, 1985, p.41).

Embora a grande quantidade de exemplares esteja plantada em canteiros centrais o que poderia caracterizar uma arborização plantada em espaços amplos, a 


\section{COMPATIBILIDADE DA ARBORIZAÇÃO DE RUAS EM CENTROS HISTÓRICOS: ESTUDO DE CASO DE SÃO GABRIEL - RS}

realidade é muito contrária e fica explicita ao verificar o gráfico 4 onde $83,56 \%$ dos vegetais formadores da arborização do Centro Histórico estão em área livre restrita, ou seja, em espaço inferior a $0,5 \mathrm{~m}^{2}$.

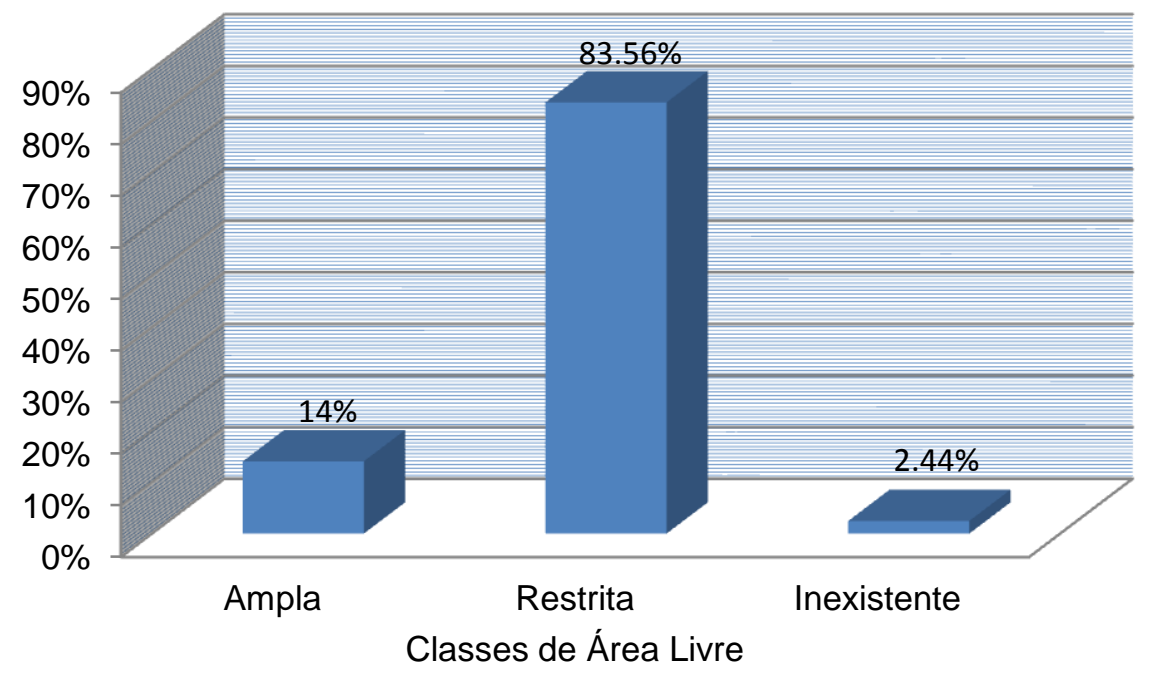

Gráfico 4 - Distribuição das classes de área livre dos exemplares arbóreos ocorrentes na arborização viária do Centro Histórico de São Gabriel - RS.

Schallenberger e Machado (2013, p.61) ao avaliar a arborização da região central do município de Mangueirinha-PR observaram durante o inventário que em sua maioria as árvores se encontravam condicionadas em uma área permeável de apenas $0,45 \mathrm{~m}^{2}$, ou seja, menor ainda que em São Gabriel-RS.

Conforme Raber e Rebelato (2010, p. 195), a falta de área livre (espaço livre que permite a infiltração de águas e nutrientes para a planta) provoca um desenvolvimento inadequado das plantas e a utilização de espécies com sistema radicular pouco profundo numa área pequena pode comprometer a calçada, em função da pressão exercida pelas raízes.

A arborização de ruas do Centro Histórico demonstrou a sua irregularidade de distribuição através dos dados referentes à distância da esquina até a primeira árvore (gráfico 5). Os percentuais das classes entre 0,0 até $5 \mathrm{~m}$ e 5,01 até $10 \mathrm{~m}$ perfazem $53,05 \%$ porém alta também é a percentagem dos exemplares com distância acima de $30 \mathrm{~m}$ (26,09\%). Observa-se que em todas as classes propostas existiram exemplares corroborando ainda mais o que se observa in loco ao longo das vias do município. 


\section{COMPATIBILIDADE DA ARBORIZAÇÃO DE RUAS EM CENTROS HISTÓRICOS: ESTUDO DE CASO DE SÃO GABRIEL - RS}

Em Lageado-RS, 22,4 \% da ocorrência das árvores localizaram-se a menos de $5 \mathrm{~m}$ da esquina (RUSCHEL e LEITE, 2002, p.15), enquanto que em Campo Grande (MT) apenas $1 \%$ da população amostrada localiza-se a menos de $5 \mathrm{~m}$ da esquina interferindo na visibilidade dos motoristas (MANUAL DE ARBORIZAÇÃO DE CAMPO GRANDE, 2010, p.77).

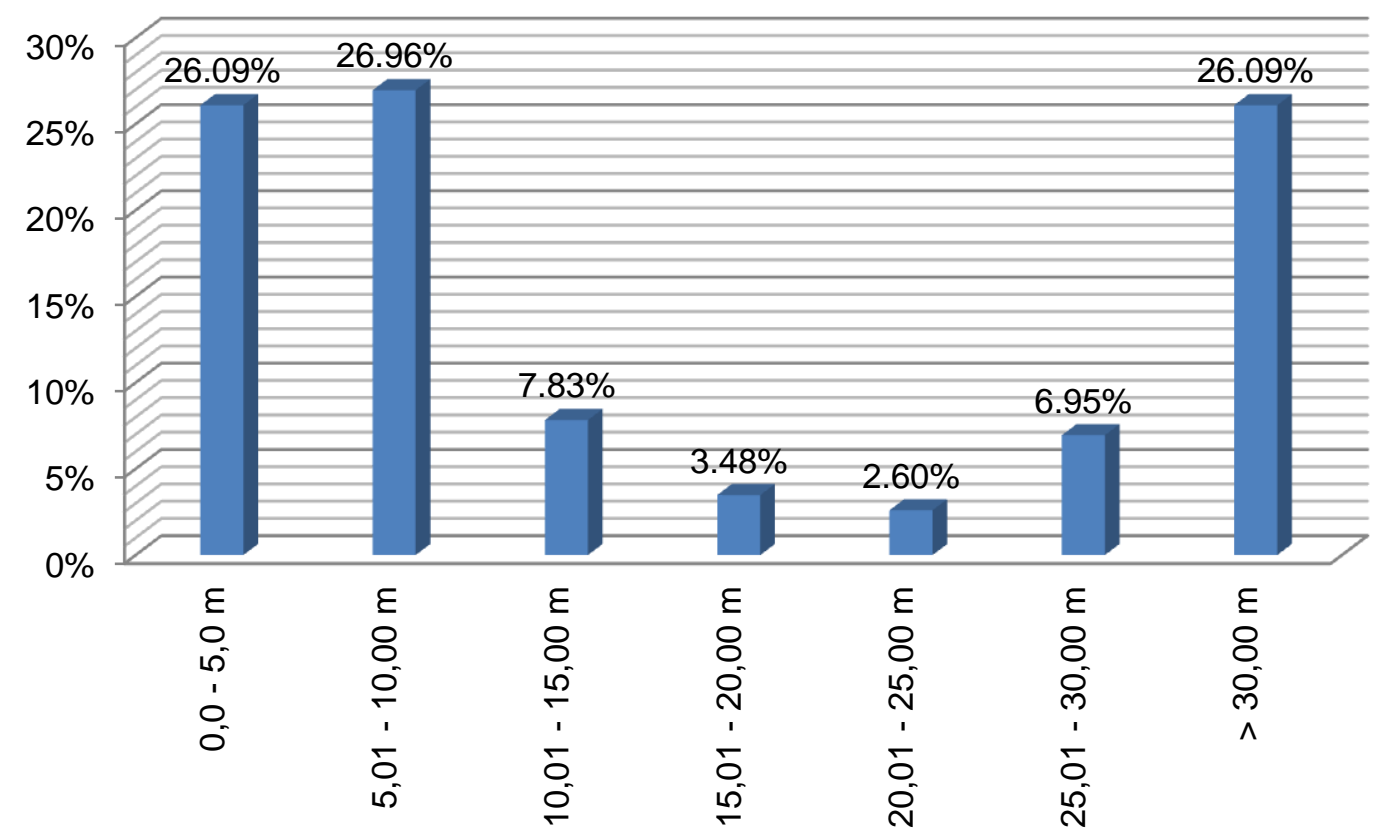

Distância da esquina à primeira árvore

Gráfico 5 - Distribuição das classes de distância da esquina ao primeiro exemplar arbóreo ocorrente na arborização viária do Centro Histórico de São Gabriel - RS.

Considerando a primeira classe $(0,0-5,0 \mathrm{~m})$ fica explicito a falta de critério no plantio dos exemplares. Evidente também é o plantio espontâneo dos moradores não observando distâncias específicas, pois cada município possui um código de postura onde estabelece valores mínimos da distância da esquina para plantio de árvores e colocação de placas. Cabe ressaltar também a falta de fiscalização sobre o tema pelo Poder Público. Em contraponto os valores igualmente altos de exemplares com distância acima dos $30 \mathrm{~m}$.

Este fato denota a carência de arborização nas ruas do Centro Histórico o que reflete de um modo bastante claro o quadro geral do município de São Gabriel-RS.

Araújo e Araújo (2011, p.23) comentam que existem distanciamentos mínimos de árvores para estruturas formadoras das ruas como da esquina de ruas deve ser 


\section{COMPATIBILIDADE DA ARBORIZAÇÃO DE RUAS EM CENTROS HISTÓRICOS: ESTUDO DE CASO DE SÃO GABRIEL - RS}

de no mínimo $9 \mathrm{~m}$, entrada de carros, de no mínimo $4,5 \mathrm{~m}$ e de hidrantes e postes deve ser de no mínimo $3 \mathrm{~m}$.

O compasso mais frequente foi representado pela classe de 0,0 a 5,0 m com $46,39 \%$ dos exemplares distribuídos na mesma (gráfico 6).

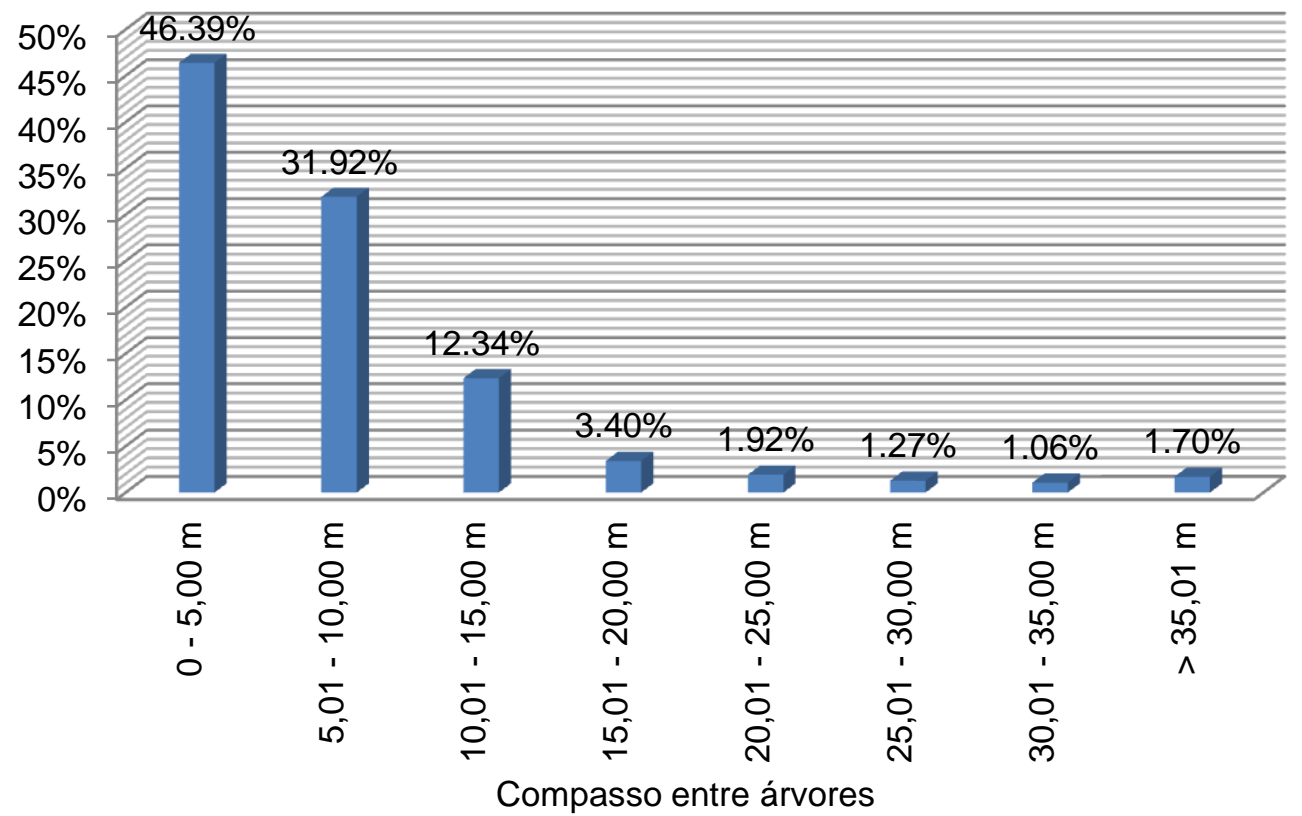

Gráfico 6 - Distribuição das classes de compasso entre os exemplares arbóreos ocorrentes na arborização viária do Centro Histórico de São Gabriel - RS.

A falta de conhecimento sobre as espécies vegetais fica claro quando analisamos o compasso, pois muitas árvores são de médio até grande porte. Quando se efetua o plantio deve haver a previsão de um crescimento espacial através do diâmetro médio de copa. Isto pode gerar um conflito das copas e impedir ou até prejudicar o crescimento retilíneo de um exemplar. Outra ação decorrente do compasso é a competição por luz solar fazendo com que ocorra um maior crescimento em altura de um exemplar em detrimento de outro, principalmente quando não são da mesma espécie o que acarreta sombreamento e desvio do tronco para evitar o conflito e em consequência gerando a tortuosidade muito frequente.

Existe certa tendência de árvores serem plantadas muito próximas umas das outras, para dar um impacto visual imediato. Um dos problemas de espaçamentos muito próximos é a transmissão de doenças por meio das raízes ou copas. Outro 
problema, que não é tão evidente, é o impacto no custo de manutenção no futuro. As árvores plantadas, muito próximas umas das outras, podem aumentar o custo de poda à medida que elas cresçam. O sombreamento mútuo das árvores pode causar mais galhos mortos. As árvores muito próximas sofrem estresse, deixando-as mais suscetíveis a doenças e ataques de insetos e fungos (ARAUJO e ARAÚJO, 2011, p.23).

O espaçamento médio encontrado por Sampaio (2006, p.88) em Maringá-PR foi de 12,06 metros, sendo que os diâmetros de copa em sua maioria nas principais espécies tiveram médias variando de 10 a 12 metros, podemos dizer que os espaçamentos estão condizentes com a realidade das espécies da arborização das vias. Flores (2005, p.25) também comenta que o espaçamento deve proporcionar um bom desenvolvimento para cada espécie de acordo com o diâmetro de sua copa e altura. Espaçamentos inadequados tenderão a gerar uma forte competição por espaço, luz, água, nutrientes e em consequência acarretando árvores mal formadas que não prestarão os serviços ecológicos tão requeridos pelas cidades. Recomenda também espaçamento de 8,0 m como referência para árvores de tamanho médio.

Nas vias do Centro Histórico onde a arborização está localizada nas calçadas observa-se que 41,60\% da vegetação plantada estão entre 1,51 até $2 \mathrm{~m}$ de distância do muro (gráfico7). Esta informação vem corroborar os dados referentes a grande quantidade de espécies vegetais com classes de distância ao meio fio de até 0,5 $\mathrm{m}$. Para explicitar ainda mais o potencial conflito espacial observa-se que $26,28 \%$ da vegetação inventariada está na classe de 1 até $1,5 \mathrm{~m}$ determinando assim necessidades de atenção a um manejo futuro para as mesmas.

Sampaio (2006, p.87) observou em Maringá-PR, o valor médio da distância do eixo da árvore até as construções (inicio doslotes) analisadas foi de 3,17 metros, abaixo do encontrado em Curitiba com 3,5m (MILANO, 1984) e superior ao encontrado em Recife de 2 m (BIONDI,1985). 


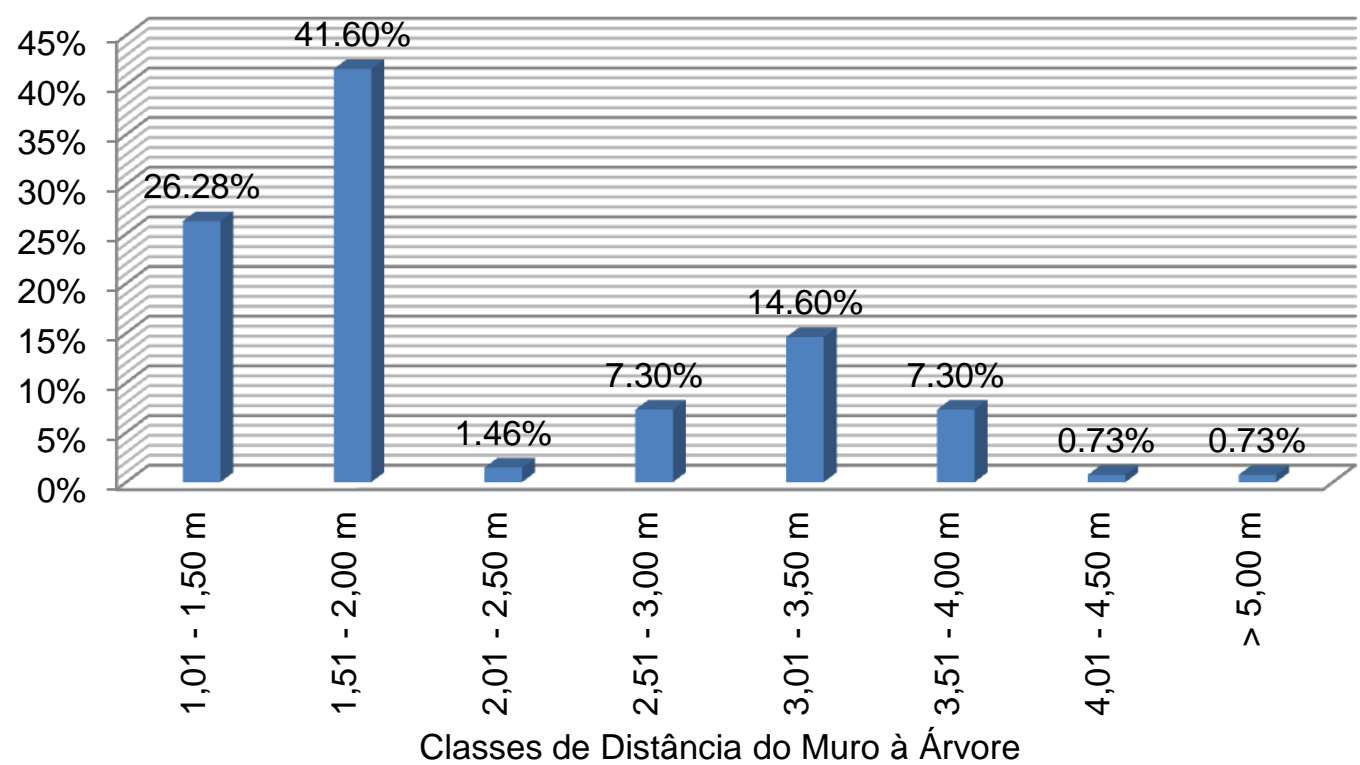

Gráfico 7 - Distribuição das classes de distância do muro aos exemplares arbóreos ocorrentes na arborização viária do Centro Histórico de São Gabriel - RS.

O gráfico 8 demonstra 0 alto grau de interferência da copadas árvores em relação aos demais exemplares arbóreos, infraestrutura, veículos e pedestres no Centro Histórico de São Gabriel-RS. O elevado índice de interferência é um resultado taxativo do processo de arborização que vem ocorrendo neste local e de um modo geral em toda cidade de São Gabriel-RS onde se denota a falta de política pública específica para este setor ficando o munícipe como o protagonista de um evento onde o mesmo deveria ser apenas o receptor desta ação por tratar-se de um item importante de qualidade de vida e uma forma de retorno da alta carga de impostos paga no Brasil.

Este grau de interferência é também observado na arborização urbana em outros municípios, como demonstra Ruschel e Leite (2002, p.16), em Lageado-RS, onde a interferência da copa foi registrada em $23,9 \%$ do total da vegetação inventariada, sendo deste total dividido em $42,13 \%$ de ocorrências sobre a fiação, $22,55 \%$ de ocorrências relacionadas a pedestres, $20 \%$ relacionadas a imóveis e $15,32 \%$ sobre veículos. A interferência sobre afiação foi ausente em alta tensão, rara na baixa tensão e mais frequente sobre a fiação telefônica. 


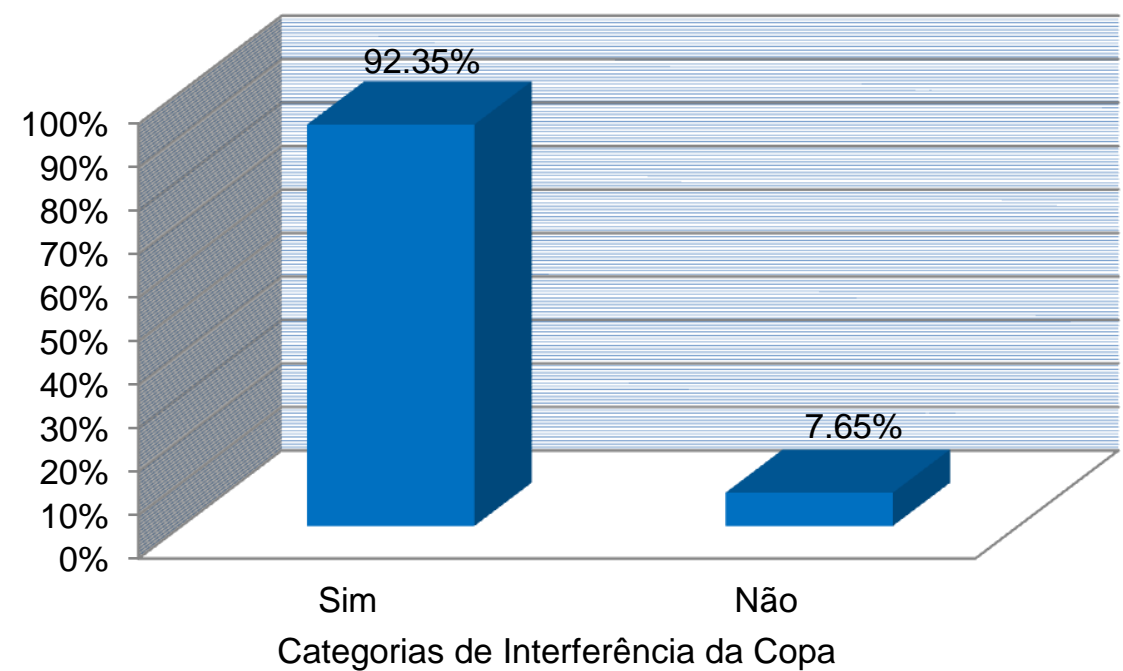

Gráfico 8 - Distribuição das classes interferência das copas dos exemplares arbóreos ocorrentes na arborização viária do Centro Histórico de São Gabriel - RS.

Em relação a interferência da copa das árvores na fiação elétrica, Nunes et al (2013, p.71) ao inventariar a arborização do bairro Ferrarópolis, Garça-SP, identificaram que 14,2\% apresentaram interferência. Essa proporção de indivíduos interferindo na fiação provavelmente ocorreu devido as diversas manutenções das espécies arbóreas de porte alto além da presença de arbusto com porte baixo que não alcançam a fiação.

Através do gráfico 9 observa-se a compatibilização das espécies vegetais no Centro Histórico do município de São Gabriel. São incompatíveis aproximadamente $58 \%$ corroborando a interferência das copas analisada anteriormente. Neste item observa-se que não apenas os erros cometidos pelos munícipes, mas ações do Poder Público em arborizar canteiros centrais muito estreitos contribuíram em muito para geração deste alto percentual.

Medeiros e Dantas (2007, p.7) ao avaliar os danos causados pela arborização de ruas na cidade de Campina Grande-PB observaram que os danos mais frequentes são os causados à estrutura das casas $(28,5 \%)$, as calçadas $(20,8 \%)$ e aos muros residenciais $(13,4 \%)$ indicando provavelmente que o espaço físico destinado ao crescimento e ao desenvolvimento dessas árvores é incompatível com o seu porte, diâmetro e extensão das raízes e da copa. Tais danos seriam minimizados se a espécie a ser cultivada fosse adequada ao local de plantio. 


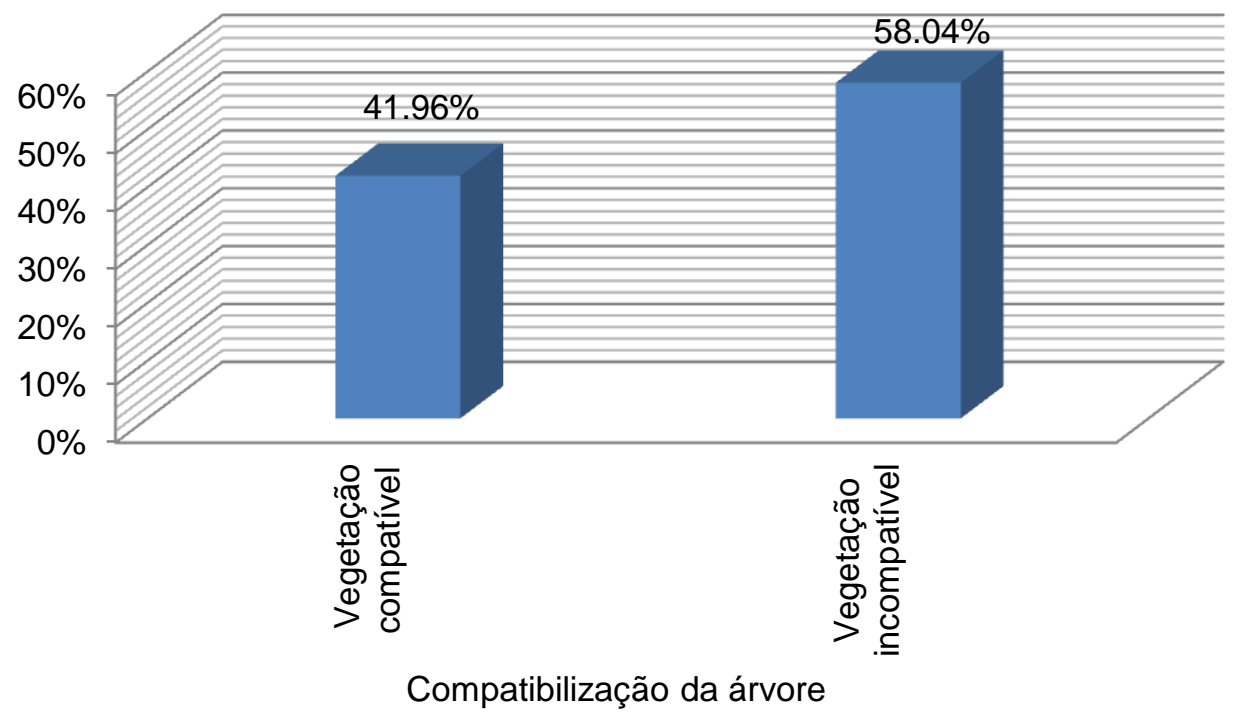

Gráfico 9 - Distribuição das classes de compatibilização dos exemplares arbóreos ocorrentes na arborização viária do Centro Histórico de São Gabriel - RS.

A expressiva maioria dos exemplares arbóreo-arbustivos apresenta interferência de sua copa de alguma forma seja nos transeuntes, nos veículos, construções e mesmos nos demais constituintes da arborização de ruas do Centro Histórico. Este resultado corrobora a situação supracitada da maioria apresentar incompatibilidade e mostra um horizonte de grande necessidade de manejo nesta vegetação para evitar maiores danos e perdas significativas de uma já parca quantidade de exemplares.

\section{CONCLUSÕES}

O espaço edificado nos centros urbanos não é um fenômeno recente, mas tem a sua gênese no final do século XIX passando por vários processos de mudança tanto em sua forma quanto em seu conteúdo. Constitui-se o local onde ocorrem as mais intensas alterações antropogênicas. A vegetação arbórea entra neste ambiente conflitando com o espaço tridimensional ocupado pelo elemento construído e notadamente verticalizado.

Em São Gabriel - RS pelo conjunto arquitetônico modelado pela arquitetura espanhola de época demonstra exatamente estas características assim como a ausência do planejamento espacial para a vegetação no meio urbano. 
A situação expressada nos números apresentados do censo da arborização do Centro Histórico de São Gabriel-RS denota os problemas de ausência de políticas públicas voltadas para o estabelecimento de ações específicas para este setor de grande importância para a qualidade de vida dos munícipes e do próprio ambiente. Uma área do município de grande valor histórico no que tange ao aspecto arquitetônico urge por compatibilizar a sua preservação aos complementos como uma arborização adequada e que transformariam este local em um atrativo turístico para esta região aliado aos demais que já existem.

\section{REFERÊNCIAS}

ALVES, F. M. B. Avaliação da qualidade do Espaço Público Urbano. Propostametodológica. Textos Universitários de Ciências Sociais e Humanas, Lisboa: Dinalivro; 352 p, 2003.

ALVEY, A. A. Promoting and preserving biodiversity in the urban forest. Urban Forestry \& Urban Greening, n.5, p. 195-201, 2005.

ARAUJO, A. J.; ARAUJO, M. N. de. Arborização Urbana. Série Cadernos Técnicos. Curitiba: CREA-PR. 2011. 40 p.

BIONDI, D. Diagnóstico da Arborização de Ruas da Cidade de Recife. 1985. 167 f. Dissertação (Programa de Pós-Graduação em Engenharia Florestal) Universidade Federal do Paraná,Curitiba, 1985.

BOHIGAS, O. Valorización de la periferia y recuperacióndel centro. Recuperacióndel frente marítimo; In: Maragall, Pasqual; Europa, Regiones y Ciudades, Europa Próxima. Edições da Universidade de Barcelona, 1999.

BONAMETTI, J. H. Arborização urbana. Terra e Cultura.Londrina-PR, n.36, p:51-55, 2003.

CÁVEM, M. Centros históricos contemporâneos: mudanças de perspectiva na gestão - caso de estudo de Lisboa e Bruxelas; 2007. Dissertação (Mestrado em Geografia Humana, PlaneamentoRegional e Local) - Universidade de Lisboa, Lisboa, 2007

EMER, A. A.; BORTOLINI, C.E.; ARRUdA, J. H.; ROCHA, K. F., MELLO, N. A. Valoração da flora local e sua utilização na arborização das cidades. Synergismus scyentifica, Pato Branco-PR, v.6,n.1, p.21-31. 2011. 
FLORES, G. J. A. El arbolado urbano em el área metropolitana de Monterrey. Ciencia UANL, Monterrey-ME, vol. VIII, nº. 1, p. 20-32, 2005.

FOSTAD, O.; PEDERSEN, P. A. Vitality, variation, and causes of decline of trees in Oslo Center (Normay).Journal of Arboriculture, Champaign,v. 23, n. 4, p. 155 165, 1997.

ISERNHAGEN, I.; SILVA, S. M.; GALVÃO, F. Listagem de espécies arbustivoarbóreas citadas nos trabalhos de fitossociologia florestal no Paraná, Brasil: uma introdução aos programas de recuperação de áreas degradadas (RAD). In: A fitossociologia florestal no Paraná e os programas de recuperação de áreas degradadas: uma avaliação. Piracicaba: IPEF, 2002. v.1.p.51-134.

INSTITUTO BRASILEIRO DE GEOGRAFIA E ESTATÍSTICA. Cidades. Disponível em: <http://www.cidades.ibge.gov.br> Acesso em: 12 de mar.2014.

MASCARÓ, L., MASCARÓ, J. L. Vegetação urbana. 3rd ed. Porto Alegre: Masquatro Editora; 2010. 212 p.

MARQUES, T. S. Portugal na Transição do Século - Retratos e dinâmicas territoriais. Edições Afrontamento, 2005; 170 p.

MEDEIROS, L. S.; DANTAS, I. C. Danos causados ao patrimônio público e particular na cidade de Campina Grande/PB por espécies indevidamente utilizadas na arborização urbana. Revista de Biologia e Farmácia, Campina Grande - PB, vol. 1, n.1. p. 10-20. 2007.

MILANO, M. S. Avaliação e Análise da arborização de ruas de Curitiba-PR. 1984. 120 f. Dissertação (Programa de Pós-Graduação em Engenharia Florestal) Universidade Federal do Paraná.Curitiba,1984.

NUNES, R. L.; MARMONTEL, C. V.F.; RODRIGUES, J.P.; MELO, A.G.C. Levantamento qualiquantitativo da arborização urbana do Bairro Ferrarópolis na cidade de Garça-SP. REVSBAU, Piracicaba - SP, v.8, n.1, p.65-74, 2013.

PAIVA, H. N.; GONÇALVES, W. Árvores para o ambiente urbano. Viçosa: Editora Aprenda Fácil,242 p. 2004.

PLANO DIRETOR DE ARBORIZAÇÃO DE CAMPO GRANDE. Prefeitura Municipal de Campo Grande/MT. 158p. 2010.

PIVETTA, K. F. L.; SILVA FILHO, D. F. Arborização urbana. Jaboticabal: UNESP, FCAV, FUNEP, 2002. 69p. (Boletim Acadêmico).

RABER, A.P., REBELATO, G. S. Arborização viária do município de Colorado-RS Brasil: análise quali-quantitativa. REVSBAU, Piracicaba -SP; v.5, n.1, p.183-190, 2010. 
ROBERT, P.; SYKES, H. Urban Regeneration, a handbook. British Urban Regeneration Association. Sage Publications, 2004.320 p.

RUSCHEL, D.; LEITE, S. L. C. Arborização urbana em uma área da cidade de Lajeado, Rio Grande do Sul, Brasil.Caderno de Pesquisa Sér. Bio., Santa Cruz do Sul-RS, v. 14, n. 1, p. 07-24. 2002.

SALGUEIRO, T. B. A cidade em Portugal - Uma geografia urbana; Coleção Cidade em Questão / 8; Porto: Edições Afrontamento; 3a edição; 1999.

SALGUEIRO, T. B.. Paisagens Urbanas. In:MEDEIROS, C. A. (coord.), Geografia de Portugal - Sociedade, Paisagens e Cidades, volume 2; Lisboa: Círculo de Leitores; 2005, cap 3, p.78 - 93.

SALVI, L. T.; HARDT, L. P. A.; ROVEDDER, C. E., FONTANA, C. S.Arborização ao longo de ruas - túneis verdes em Porto Alegre, RS, BRASIL: avaliação quantitativa e qualitativa. Revista Árvore, Viçosa-MG, v.35, n.2, p.233-243, 2011.

SAMPAIO, A. C. F. Análise da arborização de vias públicas das principais zonas do Plano Piloto de Maringá-PR. 2006, 144 p. Dissertação (Programa de PósGraduação emGeografia, área de Concentração:Análise Regional e Ambiental). Universidade Estadual de Maringá, Maringá, 2006.

PREFEITURA MUNICIPAL DE SÃO GABRIEL - Plano Diretor de Desenvolvimento Urbano e Ambiental, 2008. Disponível em: <http://www.saogabriel.rs.gov.br>. Acesso em: 10 de agost. 2014.

SCHALLENBERG, L. S.; MACHADO, G. O. Inventário da arborização na região central de Mangueirinha- PR.REVSBAU, Piracicaba - SP, v.8, n.1, p.54-64, 2013.

SILVA, L. M.; HASSE, I.; MOCELLIN, R.; ZBORALSKI, A. R. Arborização de vias públicas e utilização de espécies exóticas: ocaso do bairro Centro de Pato Branco/PR. Scientia Agraria, Curitiba-PR, v.8,n.1, p.47-53, 2007.

SILVA FILHO, D. F.; BORTOLETO, S. Uso de indicadores de diversidade na definição de plano de manejo da arborização viária de Águas de São Pedro SP.Revista Árvore, Viçosa-MG, v.29, n.6,p.973-982, 2005.

SPIRN, A. W. O jardim de granito: a natureza no desenho da cidade. São Paulo: Editora da Universidade de São Paulo, 1995.

VELASCO, G. D. N.; LIMA, A. M. L. P.; COUTO, H. T. Z.do.Análise comparativa dos custos de diferentes redes de distribuição de energia elétrica no contexto da arborização urbana. Revista Árvore, Viçosa-MG, v.30 n.4, p. 679-686. 2006. 